\title{
Manufacturing Flexibility and Operational Performance of Pharmaceutical Manufacturing Companies in Jordan
}

\author{
Bahjat Eid Al-jawazneh (Assistant Professor) \\ Department of Business Administration, Faculty of Business \& Finance \\ Al-albayt University, Mafraq, Jordan \\ E-mail: jawazneh9@yahoo.com
}

Received: October 26, 2011

Accepted: December 2, $2011 \quad$ Published: February 16, 2012

doi:10.5539/ijbm.v7n4p181

URL: http://dx.doi.org/10.5539/ijbm.v7n4p181

\begin{abstract}
This study explores the effect of manufacturing flexibility on the operational performance of Pharmaceutical manufacturing firms in Jordan, variables such as of machine, volume, material handling, mix, and routing flexibilities are selected to represent the manufacturing flexibility dimension while quality, cost, speed and reliability are chosen to represent operational performance.

A survey questionnaire was distributed for that purpose to the subjects who belong to different departments or divisions in the production function. The study revealed that manufacturing flexibility is being adopted to a moderate extent, while the operational performance is impressively high. Testing hypothesis indicated that the manufacturing flexibility dimensions have a significant effect on the operational hypothesis performance of the pharmaceutical manufacturing companies, hence, the null hypothesis is rejected and the alternative hypothesis is accepted.
\end{abstract}

Keywords: Flexibility, Operational performance, Manufacturing, Pharmaceutical sector, Jordan

\section{Introduction}

Many of flexibility related studies have been conducted in developed countries, such as the United States, Japan, and countries in Western Europe. As the way of adopting flexibility concept in the manufacturing area may be different from one country to another, taking into account the different environments and economic aspects, the study of manufacturing flexibility in a third world countries such as Jordan is expected to tackle new issues involved and may not be recognized in the studies in developed countries.

The choice of conducting this research is critical for the Pharmaceutical sector, especially, nowadays where companies are exerting extra efforts to attain their goals in this volatile environment .Moreover, in order to cope up with unpredictable changes in demand, the firm needs to possess some degrees of flexibility in order to stay competitive and profitable (Bengtsson et. al., 2002). Therefore, this study provides a robust and time-tested framework for analyzing pharmaceutical industry, reflected in the plant flexibility dimensions and the operational performance.

The term flexibility has been used in many areas of management and organizational functions including finance, automation, manufacturing, health care and human resources; however, in each area the definition differs depending on the types of product or service created (Chanopas et al., 2006). Flexibility is regarded as the ability to respond to or conform to new situations and is usually classified as process, product, or infrastructure related (Noori and Radford, 1995). But one of the most comprehensive definitions was introduced by (Swamidass, 2000) who defined it as "the capacity of a manufacturing system to adapt successfully to changing environmental conditions as well as changing product and process requirements".

Flexibility improvement becomes an unavoidable skill for the managers by which they must evaluate the degree of manufacturing flexibility, implement flexibility, and measure the performances, especially in today's uncertain business environment (Gerwin, 1993). Manufacturing companies adopted various forms of Advanced Manufacturing Technology (AMT) over the past three decades for improving their performance and competitive position, therefore cost reduction, higher efficiency and better quality of the products were basically the main drivers for performance improvement (Upton, 1995).

Operational performance is an important aspect of measuring the output of plant flexibility, and it is seen as, a 
measure of how well inputs are transformed to outputs in terms of quality, speed, dependability of processes, flexibility and cost. But it must take into consideration that, customer requirements have changed over the last two decades. Operational performance indicators should therefore reflect and measure these new requirements: low prices, high quality, high variety of products as well as fast and on-time delivery (Slack, 1991; Small, 1999).

\section{Theoretical Framework and Hypothesis Conceptualization}

\subsection{Manufacturing Flexibility}

Flexibility has long been occupying the attention of operations management scholars, at a broad level, flexibility can be understood as an absorber of environmental uncertainty and variability (Gerwin, 1993; De Toni and Tonchia, 1998; Beach et al, 2000). Thus flexibility is considered a major tool which is capable of meeting the challenges posed by uncertain environment. Upton's (1994) also defined it as "the ability to change or react with little penalty on time, effort, cost or performance". (Koste and Malhotra 1999) recognized ten dimensions of flexibility and introduced a hierarchy of flexibility dimensions ranging from individual resource, to shop floor, plant, functional and business unit.

Carlsson (1989) identified three major types of flexibility: operational (short-term), tactical (medium-term) and strategic (long-term). Operational flexibility is the embedded processes that permit a large range of responses to operational variables such as sequencing, scheduling...etc. Tactical flexibility refers to the embodiment in technological and organizational routines of responses in how to deal with quantitative and qualitative changes in rates of production, product mix over the course of a business cycle, etc. Strategic flexibility exemplifies how the firm is positioning itself with respect to future challenges and opportunities.

Suarez et al. (1995) argued that a company's competitiveness is determined by its ability to meet the needs of the consumers in terms of quality, efficiency and flexibility .He even pointed out that more volatile markets, shorter PLC and more sophisticated buyers have all contributed to flexibility's emergence as a new strategic imperative. Therefore flexibility is not just a fad or a road to super performance to any company, but it is a must to those organizations that their nature of production and marketing demand them to do so.

Koste and Malhotra (1999) defined several dimensions of manufacturing flexibility that includes machine, labor, material handling, routing, operations, expansion, volume, mix, new product and modification. Each dimension of flexibility is defined by range and adaptability. Range is defined as the number of different states, such as levels, options and positions that can be achieved with existing resources, while adaptability is the ability to change from one state to another in a timely and cost effective manner.

The manufacturing flexibility system has to pertain to its capability to respond to the changing circumstances caused by the environment (Gupta and Goyal, 1989). Taking into consideration the organizational level flexibility, it is defined as the organization's ability to predict and to adapt to the changes in its environment (Volverda, 1998; Bueno, 1996). This ability is obtained through four organizational level flexible dimensions, such as, strategic attitude, manufacturing system, organizational design and human resources practices.

Koste and Malhorta (1999) identified some dimensions of manufacturing flexibility and defined them as follows:"Machine flexibility is the number and variety of operations a machine can execute without incurring high transition penalties or large changes in performance outcomes", "Volume flexibility is the extent of change and the degree of fluctuation in aggregate output level which the system can accommodate without incurring high transition penalties or large changes in performance outcomes", and "Material Handling flexibility is the number of existing paths between processing centers and the Heterogeneity of material which can be transported along those paths without incurring high transition penalties or large changes in performance outcomes." "Mix Flexibility is the number and variety of products which can be produced without incurring high transition penalties or large changes in performance outcomes." "Routing Flexibility is the number of products that have alternative routes and the extent of Variation among the routes used without incurring high transition penalties or large changes in performance outcomes."

The concept of flexibility is a complex term. It is related closely to the overall strategic plan of the firm and, at the same time, to individual production factors at the operational level. An urgent need for wider product varieties and scope, and the trend towards shorter product life cycles are some factors that make flexibility a top priority issue in Firm's manufacturing strategy (Noori, 1990).

The manufacturing flexibility has been classified according to three views; the system view, the environment-associated view, and the decision hierarchy view. The system view corresponds to the organizational structure of an organization, characterized by its functional flexibilities, such as, machine, routing, control and worker flexibility. The second relates to characteristics of internal and external environments 
surrounding manufacturing activities. Flexibility dimensions under this classification are expansion, product, mix, volume and program. The third refers to the decision hierarchy, and has three main dimensions; long term, mid-term and short-term (Hyun and Ahn, 1992).

A study was conducted by (D'Souza and William, 2000) to categorize flexibility by using a sample of manufacturing companies to identify the operational measures of manufacturing flexibility. Two generalized categories of manufacturing flexibility emerge as externally and internally driven. The externally driven manufacturing flexibility dimensions are volume and variety flexibility, while the internally driven manufacturing flexibility dimensions are process and material handling flexibility.

Manufacturing flexibility allows companies to produce the right quantity of high quality products quickly and efficiently through setting-up time reduction, cellular manufacturing layouts, preventive maintenance, quality improvement efforts and programs, and reliable suppliers. These are possible on machines and equipment, labor, material handling, and routing flexibilities (Boyer and Leong, 1996, chen, et.al, 1992). Different descriptors for manufacturing flexibility overlap; as an example, process flexibility intersects with operational flexibility. Some descriptors are aggregates of others; process

Flexibility includes routing flexibility, machine flexibility, and material handling flexibility. The concept of manufacturing flexibility is confounded because the attributes of flexibility such as range, mobility, and uniformity and the components of flexibility like machine flexibility and volume flexibility are often mingled (Barad, 1992; Gupta, 1993; Benjaafar, 1994).

\subsection{Operational Performance}

The concept of operational strategy received much attention from scholars, who shared framework of the content of operations strategy over the past two decades. Many of them view operations strategy as defined by the relative weighting of manufacturing capabilities, including low cost, quality, flexibility, and delivery. Some conceptual studies suggested also innovativeness and service as additional priorities. Empirical research and strategy theories consistently stressed the four basic capabilities (Schmenner and Swink 1998; Ward, McCreery, Ritzman, and Sharma 1998). On the other hand, the operations performance factors for manufacturing firms are well established in the operations literature, which identifies cost, flexibility, quality, dependability, and speed as critical manufacturing competitive priorities (Vickeryet al. 1997; Slack et al. 2004). Competitive priorities have been integrated in most operations strategy content models and they have proven to be a useful way of assessing operations strategy regardless the strategy formulation process (Ward et al., 1995).

Operations strategy is a pattern of decisions regarding the selection and development of capabilities - with the latter accomplished through a variety of strategic choices of operational practices and processes (Peng et al. 2008). Capability dimensions mean: conformance quality, cost efficiency, delivery dependability, flexible responsiveness, new product development and new product introduction (Noble 1995; Ward et al. 1995; Vickery et al. 1997; Ittner and Larcker 1997b; Ward et al. 1998; Ward andDuray 2000). Operations strategy should provide opportunities to help make core competencies and capabilities more tacit and untouchable. Therefore, operating excellence leads to more sustainable competitive advantages (Wright1996).

Operations performance of service delivery comprises three critical performance factors (quality, dependability, and speed) that are usually present in a service delivery system. Consistent quality, dependability of delivery, and prompt delivery (speed) are critical operations performance factors in service delivery systems (kumar et.,al., 2011), According to Stank et al. (1999), dependability or reliability is most closely associated with operations performance, as it is fundamentally concerned with dependability and accuracy of the service.

\subsection{Related Studies}

In their research on 'can flexibility improve operational performance' (Kuo and Tin, 2003), showed that only a change in flexibility has a positive influence on the change status of a firm's operational performance. Flexibility must be increased to improve the operational performance of a company undertaking risk in an operational environment. They also found that the financial crisis in Asia is an overall, worldwide change in the international operation environment. All enterprises are impacted upon, regardless of their location, industry, or function.

Aranda (2003) proves that service operations strategy has a significant positive and direct effect on service delivery performance. The fact that is especially relevant is that flexibility plays a more intense moderating role for efficiency performance measures than for customer satisfaction performance measures.

Kuo, et.al (2006) studied the effect of Flexibility on the performance of MNEs, The empirical results show that flexibility has positive and significant effects on MNEs' performance. Furthermore, Chow test finds that the contribution of flexibility to MNEs' performance does not reveal a significant structure change following 
external shock.

Another study on Fit, Flexibility and Performance in Manufacturing: Coping with Dynamic Environments, which was conducted by (Anand, 2004), shows that in addition to making investments in flexibility capabilities, managers need to be wary of the state of the environment that they operate in, and its multiple elements such as, unpredictability and volatility, and to accordingly match the types of flexibility required by their firm. The results also show that the environment plays a crucial role in determining the types of flexibility strategies that would be suitable.

Babu and Srinivasan (2010) characterized the impact of the factors batch size, setup times, priority dispatching of jobs, machine failures, rework, volume, routing and product flexibility on the performance of a job shop is studied. The findings showed that routing flexibility and machine selection rules have significant impact on the system performance. It also found that the system performance starts to deteriorate when the level of routing flexibility increases.

In a study entitled; Flexibility and performance relationships: evidence from Indian bearing manufacturing firm, (Nayak and Ray, 2010) found that there is a significant positive relationship between production system flexibility and production system performance where majority of the dimensions of flexibility found to be significant factors affecting production system performance. It also indicated that manufacturing flexibility contribute directly and indirectly to firm performance. The findings provided evidence of direct effects of manufacturing flexibility on firm performance.

In their study on the impact of mass customization practices on performances: an exploratory study of Chinese manufacturers, (Yinan and Zhao,2011) concluded that the mass customization practices can bring benefits to manufacturers in terms of both cost reduction and product/service quality improvement, which in turn boost financial performance. Moreover, they revealed that the practices of elicitation, flexibility in design, advanced manufacturing technology (AMT), just-in-time (JIT) supply chain and integrated logistics information system (ILIS) play different roles in business performance improvement.

\subsection{The Pharmaceutical sector in Jordan}

During the past forty-eight years, the Jordanian pharmaceutical industry has grown strongly in both quality and quantity. The number of specialized companies is now sixteen. The sector has become an export driven industry distributing its products on more than sixty countries due to its high quality, excellent reputation, and its affordable price. Pharmaceutical industry in Jordan is a leading exporting sector due to its high quality and excellent reputation. Therefore $81 \%$ of production is exported to foreign markets. Jordanian pharmaceuticals are now distributed worldwide in more than sixty countries and $90 \%$ of the exports are going to Arab countries. Jordanian pharmaceutical companies have joint ventures and subsidiary companies in eight Arab and foreign countries (Japm, 2011). But in spite of that, the Jordanian pharmaceutical sector in Jordan confronts challenges that are imposed on them by Jordanian admission to the World Trade Organization WTO. The WTO has subjected the local pharmaceutical industries products to fierce competition from foreign products. This fact makes these companies unable to keep pace with new developments in pharmaceutical industries (Central bank, 2006).

\section{Statement of the problem}

A research project was carried by (Ryan, M.P., \& Shanebrook J., 2004) 0n Establishing globally competitive pharmaceutical and Bio-medical technology industries in Jordan concluded that; few companies are focusing on their export and marketing capabilities in the region and beyond; a few companies are focusing on their bio-medical technology R\&D capabilities. Hence recommended that, all companies in the Jordanian pharmaceutical and bio-medical technology industry should improve their export and marketing capabilities and/or their bio-medical technology $R \& D$ capabilities and stressed that, these strategic actions increase substantially the chances that Jordanian pharmaceutical and bio-medical technology industries will survive - and may even thrive - in the global marketplace.

Inspired by the above statement, and believing that, studying the issue of manufacturing flexibility and applying it to operational strategy, will be a partial fulfillment for what (Ryan, M.P., \& Shanebrook J., 2004) recommended. Specifically, the study seeks an answer for the main research question:

What is the effect or influence of the manufacturing flexibility on the operational strategy of selected pharmaceutical companies in Jordan? 


\section{Objectives of the study}

The objectives of this study are:

- To find out the level of implementation of manufacturing flexibility at the Pharmaceutical manufacturing companies in Jordan?

- To find how the pharmaceutical companies perform in relation to quality, cost, speed and flexibility?

- To test the effect of machine flexibility, volume flexibility, material handling flexibility, mix flexibility, and routing flexibility on the operational performance of the Pharmaceutical companies' operational strategy in Jordan.

- To provide the Pharmaceutical sector in Jordan, a profound and reliable results capable of evaluating their current status regarding some dimensions of their manufacturing flexibility.

- It serves as a good indicator for such factor, and this may help these firms in either to continue adopting their current strategies or re modify them.

\section{Hypothesis of the study}

Based on the problem and the relevant literature of this study, the research hypothesis is:

H0: There is no statistically significant effect of the manufacturing flexibility selected dimensions such as, Machine flexibility, Volume flexibility, Material Handling Flexibility, Mix Flexibility, Routing Flexibility on the Pharmaceutical companies' operational performance in Jordan.

\section{The Research Conceptual Model}

\section{Insert Figure 1- here}

\section{Research Methodology}

\subsection{Study population and sampling procedures}

The study includes all public listed Pharmaceutical companies in Jordan. They are the top companies in terms of sales:

- Hikma Pharmaceuticals

- Dar Al Dawa Development and Investment Company (DADI)

- Arab Pharmaceutical Manufacturing Company (APMC)

- Middle East Pharmaceutical and Chemical Industries (MPHA)

- Hayat Pharmaceutical Industries (HPIC)

- Arab Center for Pharmaceutical and Chemical Industries Company (APHC)

A convenience sampling technique was utilized, 350 out of more than 1200 workers were selected to take part in the study. Questionnaires were distributed to those who work in the production division and are in direct relationship with the manufacturing activities. The subjects belonged to different cycles in the production function, 320 of the questionnaires were recovered, 25of which were excluded for not meeting the validation requirements, hence 295 of the questionnaires were valid for analysis.

\subsection{Data collection method}

Two types of data have been utilized in this study:

1) Primary data, which were collected through a questionnaire used for that purpose.

2) Secondary data, that were taken from different literatures and studies using respected internet research data bases to cover the theoretical side of the research.

\subsection{Research Instrument}

For the sake of credibility and taking into consideration the sensitivity and the technicality of this research topic, the researcher opted to make use of some of the manufacturing flexibility dimensions used by (Q. Zhang et. al, 2003). While operational performance elements were taken from the study of (Vickeryet al. 1997; Slack et al. 2004). The questionnaire is made off three parts:

1) Aims to collect data concerning the demographic profile of the respondents.

2) Aims to measure the respondents answers regarding the manufacturing flexibility dimensions such as, machine flexibility, volume flexibility, material handling flexibility, mix flexibility, and routing flexibility. 
3) Measures the respondents' answers on operational performance elements like, quality, cost, speed and reliability.

Nominal scale was used to allow the respondents to answer the questions related to their demographic profile. likert scale was used to allow the respondents to rate their answers on the different manufacturing flexibility dimensions and operational performance elements, which is ranging from strongly agree as the highest to strongly disagree as the lowest.

\subsection{Data analysis techniques}

The researcher used the following statistical tools:

1) Descriptive statistics measures to describe the population of the study based on percentages, and frequencies, and also to analyze the respondents' answers on the study variables through means and standard deviations.

2) Multiple regression method to know the effect of the operational flexibility represented by its dimensions on the operational performance of the Pharmaceutical manufacturing companies in Jordan.

3) Variance Inflation Factor (VIF) and Tolerance Test.

4) To make sure that there is no high correlation between the independent variable dimensions.

5) Normality Test to confirm the normal distribution of data.

6) Reliability Test (Cronbach's alpha) was employed to measure the internal consistency of the research instrument Variables, it turned out to be $83.4 \%$ which is considered high.

\subsection{Validity of the research instrument}

The researcher sought the opinions of some academicians in the field of operations management and some engineers from the Pharmaceutical sectors. Most of them confirmed the validity of the research instrument. The researcher took into consideration their opinions on the choice of the study independent and dependent variables.

\section{Data presentation, findings, and discussion of results}

\subsection{The demographic Profile of respondents}

\section{Insert Table 1- here}

The table shows that the majority of respondents are males with a percentage of 78 percent, and the rest are females. Though the females are less but this result could be an optimistic one compared to other industrial sectors in Jordan where the share of the female in the labor force is very low.

The Pharmaceutical manufacturing companies in Jordan rely heavily on young work force to occupy managerial positions. Most workers hold a bachelor degree while with just $8 \%$ hold high school degrees. This shows how eligible the workers at Pharmaceuticals companies are. Most of the respondents occupy either division head post or manufacturing supervisor post.

The table also shows that the respondents have good experience and mostly range from 5-15 years. This result is an indicator of a good work environment that may lead to more employee commitment.

Pharmaceutical companies in Jordan supply both the local and international markets with high quality medicines.

8.2 The level of the implementation of manufacturing flexibility at the pharmaceutical manufacturing companies in Jordan.

Insert Table 2- here

The table shows that, machine flexibility dimension got a high average of 3.55 , but the ability of machine to use effectively many tools got the first in ranking with an average of 4.03 , followed by the ability of machines to perform many types of operations. But they still have to improve in terms of machine setup time because it was ranked the lowest with an average of 3.21 and a standard deviation of 1.10.

Volume flexibility was rated an average with a score of 3.36. This could be taken as a good result taking the fact that the demand on medicines and other medical products is semi-stable and therefore the volume flexibility is not a major determinant of the industry competitiveness. The highest in ranking is their ability to operate at different levels efficiently with an average of 3.7 and a standard deviation of 1.08 . The lowest in rating is their ability to run various batch sizes economically.

Material handling flexibility was rated an average with a score of 3.15. The answers on all items related to this dimensions ranged from 3.25 as the highest and to 3.03 as the lowest. This average rating is possibly due to the 
high cost this dimension needs.

Mix flexibility scored an average rating of 3.21. Though for this type of industry, mix flexibility needs to be implemented at a high level because of the increase in the variability of the medicinal products mix as a result of changing research results and the new components required. Their answers ranged from a score of 3.29 as the highest and 3.08 as the lowest.

Routing flexibility was rated the lowest among the other dimensions with an average of 2.82 , which means pharmaceutical companies in Jordan have difficulty in facing problems related to line or machine breakdown, since changing operating sequence and the availability of alternative route would possibly be not easy task. We may conclude that the results in the above table somehow agree with what Boyer and Leong, 1996, Chen, et.al, 1992) arrived at.

\subsection{Operational Performance}

\section{Insert Table 3- here}

The table above shows that the average operational performance of the respondents' companies is almost 4.00 which is high and therefore they Pharmaceutical companies in Jordan perform well in terms of quality, cost, speed and reliability, this result agrees with findings of (Kuo and Tin,2003) and (Babu and Srinivasan, 2010).

The table also illustrates that, quality was rated high with a total score of 3.65 , items such as, "we are able to produce effective medicines" and "can produce consistent products with low defect rate" got the highest in rating. But their ability to produce durable medicines with long expiration dates got the lowest. This is one of the reasons why the Jordanian medicines gain good reputation in the neighboring countries and North African countries such as Algeria and Sudan.

The cost element of operational performance was rated high, scoring an average of 4.11. Most of the respondents agree that they can get materials at a very competitive price, followed by their ability to reduce the product cost by lowering the overhead cost. The last item concerning their high labor productivity contribution to the reduction of product cost got the least score which is considerably high.

The speed criterion of operational flexibility was also rated high, with a score of 4.11 . Their ability to improve total lead time of their products and the competiveness of their cycle time got a score of 4.15 and 4.08 respectively.

The reliability dimension of the operational performance was also rated high with a score of 4.13 . The item that was rated the highest with a score of 4.37 and a standard deviation of 0.78 was related to their commitment to dispatching dates. The delivery of their half processed products to the next work center on time, was rated high with an average of 4.14 and a standard deviation of 0.87 .

\subsection{Hypothesis Test}

To guarantee the suitability of data to regression analysis, it was made sure that there is no high correlation between the manufacturing flexibility variables by applying Variance inflation factor (VIF), and tolerance test for each of independent variables as shown in table 4. It was supposed that the variance inflation factor for each element of independent variables must not exceed (10), and the allowed tolerance must be more than (0.05). The table below shows that, the elements of manufacturing flexibility are less than (10) and their values are between $(1.78-2.83)$. In spite of that the value of tolerance for each of the independent variables was more than 0.05 and between $(0.35-0.55)$.This finding indicates that there is no high correlation between manufacturing flexibility variables.

To examine the normal distribution of data, a normality test was performed, by calculating the skewness factor for the independent variables. Table 4 shows that the values are less than (1), therefore they are normally distributed.

Insert Table 4- here

\subsection{The results of the test of the study hypothesis}

Insert Table 5- here

Table (5) shows that, the F- value is (5.68) with a significance of (0.001), which is less than the $0.05(0.001$ $<0.05)$, this confirms the validity of the model of the study.

Insert Table 6- here

The results of the regression analysis of the study hypothesis in the table above show the following: 
1) The manufacturing flexibility dimensions has a significant effect on the operational performance of the pharmaceutical manufacturing companies $(\alpha \leq 0.05)$, the calculated T- value is $(5.08)$ and with a significance of 0.0001 . The R-value of (0.29) shows a strong relationship between the manufacturing flexibility and the operational performance, therefore this interprets $(8.4 \%)$ of the variance in the operational performance. Hence, the null hypothesis is rejected and the alternative hypothesis has been accepted. This result is agrees with the findings of (Nayak and Ray, 2010).

2) The effect of each variable of manufacturing flexibility on the operational performance was examined and revealed that, the elements of machine and material handling flexibilities have a significant effect on the operational performance with $(\alpha \leq 0.05)$. On the other hand, volume, mix, and routing flexibilities don't have a significant effect on the operational performance of Pharmaceutical manufacturing companies in Jordan.

\section{Conclusion}

1) The level of the implementation of manufacturing flexibility at the Pharmaceutical manufacturing companies in Jordan is medium but satisfying, taking into the account that Jordan is a developing country that struggles to find a slot in a volatile global market.

2) The highest rating goes to machine flexibility dimension while the lowest was the routing flexibility. Such finding allows machines to make shifts from one type of medicine or operation to another in a short time. Programmable machines could be one of the reasons that stand behind that result .Routing flexibility needs to be improved to make firms more responsive to sudden work centers or machines breakdowns.

3) The level of operational performance is considerably very good, a high rating was given to the reliability, speed, cost and quality. This result is a no wonder for a country that positioned itself as a leader in the manufacturing of Pharmaceutical products in the region. In spite of these impressive results, firms must keep on improving their process to meet the upcoming stiff competition from other countries in the region such as Egypt and some GCC countries.

4) The manufacturing flexibility dimensions has a significant effect on the operational performance of the pharmaceutical manufacturing companies in Jordan, nevertheless, machine and material handling flexibilities have a significant effect on the operational performance, volume, mix, and routing flexibilities were found not to have a significant effect on the operational performance of Pharmaceutical manufacturing companies in Jordan. This can be an eye opener to future researchers to explore the other elements that have an effect on the operational performance.

\section{Recommendation for future research}

Flexibility subject in general and manufacturing flexibility in particular still need to be deeply explored by Jordanian researchers to find their level of practice, relevance and impact on other organizational variables. Therefore local researchers are advised to divert their efforts towards this topic of research.

Interested parties are advised to finance future research project carried by graduate students and academicians to help them overcome some financial obstacles that may negatively affect the research outcome.

\section{References}

Anand, Gopesh., \& Ward, Peter T. (2004). Fit, Flexibility and Performance in Manufacturing: Coping with Dynamic Environments. Production and Operations Management, 13(4), 369-385. http://dx.doi.org/10.1111/j.1937-5956.2004.tb00224.x

Aranda Daniel Arias. (2003). Service operations strategy, flexibility and performance in Engineering consulting firms. International Journal of Operations \&Production Management, 23(11), 1401-1421. http://dx.doi.org/10.1108/01443570310501907

Babu, B. Shoban., \& Srinivasan G. (2010). Impact of volume, routing and product mix flexibilities on the performance of a job shop: a simulation study. International Journal of Enterprise Network Management, 4(2), 107-135. http://dx.doi.org/10.1504/IJENM.2010.037930

Barad, M. (1992). Impact of some flexibility factors in FMSs a performance evaluation approach. International Journal of Production Research 30(11), 2587-2602. http://dx.doi.org/10.1080/00207549208948178

Beach, R., Muhlemann, A.P., Price, D. H. R., Paterson, A., \& Sharp, J. A. (2000). A review of manufacturing flexibility. European Journal of Operational Research, 122(1), 41-57. http://dx.doi.org/10.1016/S0377-2217(99)00062-4

Bengtsson, Jens., \& Olhager. (2002). Valuation of product-mix flexibility using real options. International 
Journal of Production Economics, 78, 13-28. http://dx.doi.org/10.1016/S0925-5273(01)00143-8

Benjaafar, S. (1994). Models for performance evaluation of flexibility in manufacturing systems. International Journal of Production Research, 32(6), 1383-1402. http://dx.doi.org/10.1080/00207549408957006

Boyer, K. K., \& Leong, G. K. (1996). Manufacturing flexibility at the plant level. Omega-International Journal of Management Science, 24(5), 495-510.

Bueno, E. (1996). Business Organization Structure, Processes and Models. Ed Pyramid Madrid. Central Bank of Jordan. (2006), December. Monthly Statistical Bulletin. Amman, Research Department, 42, 1.

Chanopas, A., Krairit, D., \& Khang, D. B. (2006). Managing information technology infrastructure: anew flexibility framework. Management Research news, 29(10), 632-651. http://dx.doi.org/10.1108/01409170610712335

Chen, I. J., Calantone, R. J., \& Chung, C. H. (1992). The marketing manufacturing interface and manufacturing flexibility. Omega 20(4), 431-443. http://dx.doi.org/10.1016/0305-0483(92)90018-3

Competence-Based Competition: Theory and Practice in the New Strategic Management, Coping with Dynamic Environments. Production and Operations Management, 13(4), 369-385.

D. M. Upton. (1995). What Really Makes Factories Flexible?. Harvard Business Review, July-August issue, 74-84.

D'Souza, D. E., \& Williams, F. P. (2000). Towards a taxonomy of manufacturing flexibility dimensions. Journal of Operations Management, 18(5), 577-593. http://dx.doi.org/10.1016/S0272-6963(00)00036-X

De Toni, A., \& Tonchia. S. (1998). Manufacturing flexibility: a literature review. International Journal of Production Research, 36(6), 1587-1617. http://dx.doi.org/10.1080/002075498193183

Gerwin, D. (1993). Manufacturing Flexibility - a Strategic Perspective. Management Science, 39(4), 395-410. http://dx.doi.org/10.1287/mnsc.39.4.395

Gupta, D. (1993). On measurement and valuation of manufacturing flexibility. International Journal of Production Research, 31 (12), 2947-2958. http://dx.doi.org/10.1080/00207549308956909

Gupta, Y. P., \& Goyal, S. (1989). Flexibility of Manufacturing Systems: Concepts and Measurements. European Journal of Operation Research, 43, 119-135. http://dx.doi.org/10.1016/0377-2217(89)90206-3

Hsien-Chang Kuo, Yang Li, Lie-Huey Wang., \& Chia-Yu Ding. (2006). Flexibility and Performance of MNEs: Evidence from Taiwan. International Journal of Business, 11(4), 417-432.

Hsien-Chang Kuo, Yang Li., \& Mark Ting. (2003). Can flexibility improve operational performance? A risk analysis of the Asian financial crisis. Int. J. of Risk Assessment and Management, 4(4), 263-281. http://dx.doi.org/10.1504/IJRAM.2003.003825

Hyun, J. H., \& Ahn, B. H. (1992). A unifying framework for manufacturing flexibility. Manufacturing Review, 5(4), 251-260.

Koste, L. L., \& Malhotra, M. K. (1999). A theoretical framework for analyzing the dimensions of manufacturing flexibility. Journal of Operations Management, 18, 75-93. http://dx.doi.org/10.1016/S0272-6963(99)00010-8

Kumar, Batista., \& Maull. (2011). The Impact of Operations Performance on Customer Loyalty Measurements. European Journal of Operation Research, 43, 119-135.

Narayan C. Nayak., \& Pradip K. Ray. (2010).Flexibility and performance relationships:evidence from Indian bearing manufacturing firm. Int. J. Modelling in Operations Management, 1(1), 67-83. http://dx.doi.org/10.1504/IJMOM.2010.035255

Nayak, N. C., \& Ray, P. K. (2010). Flexibility and performance relationships: evidence from Indian

Noori, H. (1990). Managing the Dynamics of New Technology. Englewood Cliffs, NJ: Prentice-Hall.

Noori. H., \& Radford, R. Production and Operations Management. New York: McGraw Hill.

Pergamon. New York, NY, 325-48.

Production and Manufacturing Management(pp.399-412). Boston, Kluwer.

Ryan M., \& Shanebrook, J. (2004). Establishing globally competitive pharmaceutical and Bio-medical technology industries in Jordan. Achievement of the market friendly initiatives and results program. Funded by the united states agency for international development. 
Sanchez, R., Heene, A., \& Thomas, H. (Eds.). Dynamics of Competence- Based Competition: Theory and Practice in the New Strategic Management (PP. 325-48). New York, NY: Pergamon.

SCHMENNER, R. W., \& M. L. SWINK. (1998). On Theory in Operations Management. Journal of Operations Management, 17(1), 97-113. http://dx.doi.org/10.1016/S0272-6963(98)00028-X

Slack, N. (1991). The Manufacturing Advantage: Achieving Competitive Manufacturing Operations. London, UK: Mercury Books.

Slack, N., Chambers, S., \& Johnston, R. (2004). Operations Management. 4th Edition, and Harlow: FT/Prentice Hall.

Small, M. H. (1999). Assessing manufacturing performance: an advanced manufacturing technology portfolio perspective. Industrial Management \& Data Systems, 99(6), 266-277. http://dx.doi.org/10.1108/02635579910289202

Stank, T., Goldsby, T., \& Vickery, S. (1999). Effect of Service Supplier Performance on Satisfaction and Loyaltyof Store Managers in the Fast Food Industry. Journal of Operations Management, 17, 429 - 447. http://dx.doi.org/10.1016/S0272-6963(98)00052-7

Suarez, F. F., Cusumano, M. A., \& Fine, C. H. (1995). An empirical study of flexibility in manufacturing. Sloan Management Review, fall, 25-32.

Swamidass, P. M. (2000). Manufacturing flexibility. In Swamidass, P. M. (ed.) Encyclopaedia of Production and Manufacturing Management (pp. 399-412). Boston: Kluwer.

Vickery, S., Droge, C., \& Markland, R. (1997). Dimensions of Manufacturing Strength in the Furniture Industry. Journal of Operations Management, 15, 317-330. http://dx.doi.org/10.1016/S0272-6963(97)00012-0

Volberda, H. W. (1998). Building the Flexible Firm: How to Remain Competitive. New York: Oxford University Press.

Ward, P. T., Duray, R., Leong. G. K., \& Sum, C. C. (1995). Business environment, operations strategy, and performance: an empirical study of Singapore manufacturers. Journal of Operations Management, 13, 99-115. http://dx.doi.org/10.1016/0272-6963(95)00021-J

Ward, P. T., Mccreery, J. K., Ritzman, L. P., \& Sharma, D. (1998). Competitive Priorities in Operations Management. Decision Sciences, 29(4), 1035-1046. http://dx.doi.org/10.1111/j.1540-5915.1998.tb00886.x

Wright, R. W. (1996). The role of imitable vs. inimitable competences in the evolution of the Semiconductor industry. In Sanchez, R., Heene, A. and Thomas, H. (Eds.), Dynamics of Competence-Based Competition: Theory and Practice in the New Strategic Management (pp. 325-48). New York, NY: Pergamon.

Yinan, Zhang., \& Xiande, Zhao. (2011). The impact of mass customization practices on performances: an exploratory study of Chinese manufacturers. International Journal of Mass Customization, 4(1/2). http://dx.doi.org/10.1504/IJMASSC.2011.042959

Zhang, Q., Vonderembse, M. A., \& Lim. J. (2003). Manufacturing flexibility: Defining and analyzing relationships among competence, capability, and customer satisfaction. Journal of Operations Management, 21, 173. http://dx.doi.org/10.1016/S0272-6963(02)00067-0 
Table 1. Distribution of the sample of the study

\begin{tabular}{|c|c|c|c|}
\hline variable & Category & frequency & percentage \\
\hline \multirow[t]{2}{*}{ sex } & male & 230 & 78 \\
\hline & female & 65 & 22 \\
\hline \multirow{4}{*}{ Age } & Less than 30 & 80 & 27 \\
\hline & 30- less than 40 & 103 & 35 \\
\hline & 40- less than 50 & 64 & 22 \\
\hline & $50 \&$ above & 48 & 16 \\
\hline \multirow[t]{4}{*}{ Education } & High school & 8 & 3 \\
\hline & Intermediary course & 62 & 21 \\
\hline & bachelor & 160 & 54 \\
\hline & Graduate studies & 65 & 22 \\
\hline \multirow[t]{5}{*}{ Position } & Production Head & 4 & 1 \\
\hline & Division Head & 43 & 15 \\
\hline & Manufacturing supervisor & 68 & 23 \\
\hline & Engineers & 59 & 20 \\
\hline & Pharmacists, Chemists and others & 121 & 41 \\
\hline \multirow[t]{4}{*}{ Experience } & Less than 5 years & 59 & 20 \\
\hline & 5- less than 10 years & 112 & 38 \\
\hline & 10- less than 15 years & 72 & 24 \\
\hline & 15 years \& above & 52 & 18 \\
\hline \multirow[t]{6}{*}{ Company age } & \multicolumn{2}{|l|}{ Hikma Pharmaceuticals } & 33 years \\
\hline & \multicolumn{2}{|c|}{$\begin{array}{l}\text { Dar Al Dawa Development and Investment Company } \\
\text { (DADI) }\end{array}$} & 36 years \\
\hline & \multicolumn{2}{|c|}{ Arab Pharmaceutical Manufacturing Company (APMC) } & 49 years \\
\hline & \multicolumn{2}{|c|}{$\begin{array}{l}\text { Middle East Pharmaceutical and Chemical Industries } \\
\text { (MPHA) }\end{array}$} & 18 years \\
\hline & \multicolumn{2}{|c|}{ Hayat Pharmaceutical Industries (HPIC) } & 17 years \\
\hline & \multicolumn{2}{|c|}{$\begin{array}{l}\text { Arab Center for Pharmaceutical and Chemical Industries } \\
\text { Company (APHC) }\end{array}$} & 28 years \\
\hline \multirow[t]{2}{*}{ Market } & International & 6 & \\
\hline & Local & 6 & \\
\hline
\end{tabular}


Table 2. Averages, standard deviations and ranking of the respondents answers on the level manufacturing flexibility

\begin{tabular}{|c|c|c|c|c|}
\hline $\mathrm{Q}$ & Machine flexibility & Mean & $\begin{array}{c}\text { Std. } \\
\text { Deviation }\end{array}$ & Rank \\
\hline 1 & A typical machine can perform many types of operations & 3.60 & 1.06 & 2 \\
\hline 2 & A typical machine can effectively use many different tools & 4.03 & 0.92 & 1 \\
\hline 3 & Machine tools can be changed quickly & 3.28 & 1.01 & 4 \\
\hline 4 & Machine set-ups are easy & 3.62 & 1.06 & 3 \\
\hline \multirow[t]{2}{*}{5} & Machine set-up can be done quickly & 3.21 & 1.10 & 5 \\
\hline & General Mean 3.55 & & & \\
\hline Q & Volume flexibility & Mean & $\begin{array}{c}\text { Std. } \\
\text { Deviation }\end{array}$ & Rank \\
\hline 1 & We can operate efficiently at different levels of output of & 3.70 & 1.08 & 1 \\
\hline 2 & We can operate profitably at different production volumes & 3.39 & 1.18 & 2 \\
\hline 3 & We can economically run various batch sizes & 3.10 & 1.12 & 5 \\
\hline 4 & We can quickly change the quantities for our products produced & 3.30 & 0.94 & 4 \\
\hline \multirow[t]{2}{*}{5} & We can vary aggregate output from one period to the next & 3.36 & 1.04 & 3 \\
\hline & General Mean 3.37 & & & \\
\hline Q & Material Handling Flexibility & Mean & $\begin{array}{c}\text { Std. } \\
\text { Deviation }\end{array}$ & Rank \\
\hline 1 & $\begin{array}{l}\text { A typical material handling system can } \\
\text { handle different part types }\end{array}$ & 3.03 & 1.13 & 5 \\
\hline 2 & $\begin{array}{l}\text { A typical material handling system can link } \\
\text { different processing centers }\end{array}$ & 3.11 & 1.28 & 4 \\
\hline 3 & $\begin{array}{l}\text { Material handling system can move different } \\
\text { part types through manufacturing facilities }\end{array}$ & 3.21 & 1.12 & 2 \\
\hline 4 & $\begin{array}{l}\text { Material handling changeovers between } \\
\text { parts are quick }\end{array}$ & 3.25 & 1.23 & 1 \\
\hline \multirow[t]{2}{*}{5} & $\begin{array}{l}\text { Material handling tools can be changed or } \\
\text { replaced quickly }\end{array}$ & 3.18 & 1.25 & 3 \\
\hline & General Mean 3.15 & & & \\
\hline Q & Mix Flexibility & Mean & $\begin{array}{c}\text { Std. } \\
\text { Deviation }\end{array}$ & Rank \\
\hline 1 & We can vary product combinations from one period to the next & 3.17 & 1.16 & 3 \\
\hline 2 & $\begin{array}{l}\text { We can produce a wide variety of products } \\
\text { in our plants }\end{array}$ & 3.29 & 1.16 & 1 \\
\hline 3 & $\begin{array}{l}\text { We can produce different product types } \\
\text { without major changeover }\end{array}$ & 3.28 & 0.82 & 2 \\
\hline \multirow[t]{2}{*}{4} & We can changeover quickly from one product to another & 3.08 & 1.12 & 4 \\
\hline & General Mean 3.21 & & & \\
\hline Q & Routing Flexibility & Mean & $\begin{array}{c}\text { Std. } \\
\text { Deviation }\end{array}$ & Rank \\
\hline 1 & A typical part operation can be routed to different machines & 3.23 & 1.12 & 1 \\
\hline 2 & $\begin{array}{l}\text { The system has alternative routes in case } \\
\text { machines break down }\end{array}$ & 2.91 & 1.06 & 2 \\
\hline 3 & $\begin{array}{l}\text { The operating sequence through which the } \\
\text { parts flow can be changed }\end{array}$ & 2.61 & 1.12 & 4 \\
\hline 4 & $\begin{array}{l}\text { Machine visitation sequence can be changed } \\
\text { or replaced quickly }\end{array}$ & 2.54 & 1.21 & 5 \\
\hline \multirow[t]{2}{*}{5} & Route changeovers are easy & 2.82 & 1.39 & 3 \\
\hline & General Mean 2.82 & & & \\
\hline
\end{tabular}


Table 3. Averages, standard deviations and ranking of the respondents answers on level of the operational performance

\begin{tabular}{|c|c|c|c|c|}
\hline Q & Quality & Mean & $\begin{array}{c}\text { Std. } \\
\text { Deviation }\end{array}$ & Rank \\
\hline 1 & We are able to produce effective medicines & 3.80 & 1.03 & 1 \\
\hline 2 & We can improve the our products manufacturing Formulas & 3.65 & 1.14 & 3 \\
\hline 3 & We can produce consistent products with low defect rate & 3.76 & 1.03 & 2 \\
\hline \multirow[t]{2}{*}{4} & We are able to produce durable medicines with long expiration dates & 3.51 & 1.11 & 4 \\
\hline & General Mean 3.65 & & & \\
\hline Q & Cost & Mean & $\begin{array}{c}\text { Std. } \\
\text { Deviation }\end{array}$ & Rank \\
\hline 1 & We can get our materials at a very competitive price & 4.04 & 0.83 & 1 \\
\hline 2 & We are able to reduce the product cost by lowering the overhead cost & 3.98 & 0.92 & 2 \\
\hline \multirow[t]{2}{*}{3} & Our product cost has decreased because labor productivity increased & 3.86 & 0.91 & 3 \\
\hline & General Mean 3.96 & & & \\
\hline Q & Speed & Mean & $\begin{array}{c}\text { Std. } \\
\text { Deviation }\end{array}$ & Rank \\
\hline 1 & $\begin{array}{l}\text { Total lead time (i.e. time from customer order to physical } \\
\text { delivery) of our products can be improved significantly }\end{array}$ & 4.15 & 0.96 & 1 \\
\hline \multirow[t]{2}{*}{2} & $\begin{array}{l}\text { Our manufacturing cycle time (i.e. time to manufacture a } \\
\text { Finished product from raw materials in stock) is competitive. }\end{array}$ & 4.08 & 0.82 & 2 \\
\hline & General Mean 4.11 & & & \\
\hline Q & Reliability & Mean & $\begin{array}{c}\text { Std. } \\
\text { Deviation }\end{array}$ & Rank \\
\hline 1 & $\begin{array}{l}\text { Our manufacturing work centers generally attain production } \\
\text { schedules. }\end{array}$ & 3.98 & 0.85 & 4 \\
\hline 2 & $\begin{array}{l}\text { Actual dispatch dates of final products to our customers } \\
\text { conforms planned dispatch dates }\end{array}$ & 4.37 & 0.78 & 1 \\
\hline 3 & $\begin{array}{l}\text { In our plant, manufacturing work centers deliver semi-finished } \\
\text { products to the next work center on time }\end{array}$ & 4.14 & 0.87 & 2 \\
\hline
\end{tabular}

Table 4. Variance inflation factor (VIF), tolerance and skewness factor

\begin{tabular}{|l|c|c|c|}
\hline Variables & Variance Tolerated & Variance Inflation Factor & Skewness Factor \\
\hline Machine Flexibility & 0.559 & 1.78 & 0.57 \\
\hline Volume Flexibility & 0.353 & 2.83 & 0.37 \\
\hline Material Handling Flexibility & 0.380 & 2.49 & 0.18 \\
\hline Mix Flexibility & 0.368 & 2.71 & 0.14 \\
\hline Routing Flexibility & 0.467 & 2.14 & 0.17 \\
\hline
\end{tabular}


Table 5. Variance analysis test for the first hypothesis

\begin{tabular}{|l|c|c|c|c|c|}
\hline Variance source & $\begin{array}{c}\text { Degree of } \\
\text { freedom }\end{array}$ & $\begin{array}{c}\text { Sum of } \\
\text { squares }\end{array}$ & $\begin{array}{c}\text { Average of } \\
\text { squares }\end{array}$ & F- value & Significance \\
\hline Regression & 5 & 9.53 & 1.91 & 5.67 & 0.001 \\
\hline Error & 288 & 96.84 & 0.34 & \multicolumn{2}{|l}{} \\
\hline Total & 294 & 106.39 & &
\end{tabular}

Table 6. Multiple regression analysis

\begin{tabular}{|l|c|c|c|c|c|c|}
\hline Variables & B & Beta & $\begin{array}{c}\text { T-calculated } \\
\text { value }\end{array}$ & Significance & $\mathrm{R}$ & R square \\
\hline Machine Flexibility & 0.18 & 0.25 & 4.60 & 0.035 & 0.26 & 0.068 \\
\hline Volume Flexibility & 0.16 & 0.23 & 3.85 & 0.627 & 0.23 & 0.049 \\
\hline $\begin{array}{l}\text { Material Handling } \\
\text { Flexibility }\end{array}$ & 0.14 & 0.26 & 4.42 & 0.0000 & 0.25 & 0.061 \\
\hline Mix Flexibility & 0.14 & 0.24 & 4.41 & 0.579 & 0.24 & 0.055 \\
\hline Routing Flexibility & 0.15 & 0.24 & 4.19 & 0.331 & 0.24 & 0.056 \\
\hline $\begin{array}{l}\text { Manufacturing } \\
\text { flexibility in general }\end{array}$ & 0.22 & & 5.08 & 0.0001 & 0.29 & 0.084 \\
\hline
\end{tabular}

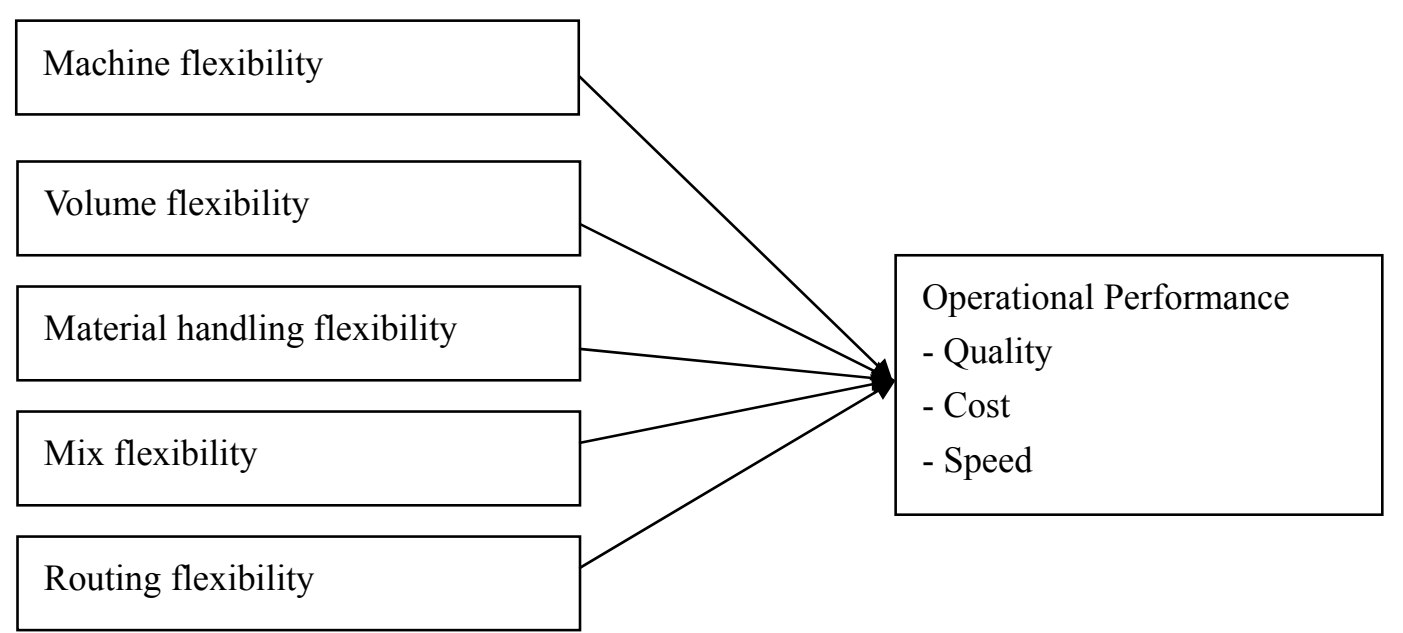

Figure 1. Research Conceptual Model

*The manufacturing flexibility variables were taken from the research of (Q. Zhang et. al, 2003) while operational performance elements were gotten from the paper of (Vickeryet al. 1997; Slack et al. 2004). 